\title{
THE SPECIES COMPOSITION ON AGRICULTURAL TERRACES IN NW PART OF SLOVAKIA
}

\author{
IVA MACHOVÁ, KAREL KUBÁT
}

Jan Evangelista Purkyně University in Ústí nad Labem, Faculty of Environment, Králova výšina 7, 40096 Ústí nad Labem, Czech Republic; e-mail: iva.machova@ujep.cz

Jan Evangelista Purkyně University in Ústí nad Labem, Faculty of Science, Za Válcovnou 8, 40096 Ústí nad Labem, Czech Republic; e-mail: karel.kubat@ujep.cz

\begin{abstract}
Machová I., Kubát K.: The species composition on agricultural terraces in NW part of Slovakia. Ekológia (Bratislava), Vol. 33, No. 4, p. 307-320, 2014.

The article contributes to a deeper understanding of agricultural terraces in NW Slovakia. The agricultural terraces found in 12 mountain ranges were characterised in detail on 32 localities. The slope parts of the studied terraces are on average only $2.3 \mathrm{~m}$ wide and current and former agricultural areas between them are on average $11 \mathrm{~m}$ wide. Furthermore, seventy phytosociological relevés were made on the terraces. Overall, 360 species of vascular plants were found in the relevés, 66 of which appeared regularly. The localities were evaluated by DCA analysis. The main factor influencing the species composition appears to be the geological composition of the bedrock and, probably, the altitude as well. High coverage of the herb layer (median value 95\%), low coverage of the shrub layer (median value 5\%) and the absence or a very low coverage of the tree layer is typical for these terraces.
\end{abstract}

Key words: NW Slovakia, agricultural terraces, vascular plants species, properties of the terraces.

\section{Introduction}

European typology subsumes the studied type of landscape under the landscape megatype: semibocage. Under the influence of social changes in the years 1950-1980 this type of landscape was on the decline, which sparkled the interest of the scientific community.

A number of authors studied hedgerows (agricultural hedgerows, agrarian hedgerows, agricultural terraces, heaps, walls, etc) in the Czech Republic, e.g. Gábová (1997), Machová, Klazar (2005), Riezner (2007), Machová, Novák (2008), Machová et al. (2008), Sklenička et al. (2009), Machová et al. (2009), Machová, Kubát (2012). From the Slovakian region come studies focusing on spreading the landscape type with hedgerows (Lobotka, 1955; Dobrovodská, Štefunková, 1996).

This study is based on a field research made in NW Slovakia - ranging from the borders with Moravia to central Slovakia. The territory of Slovak Republic differs from that of the Czech Republic by, among other things, a larger portion of sloped areas, which led to a greater degree of agricultural cultivation of slopes. For that reason, terraces as a form of anti-erosion measures were built. The flat part of the terrace was originally used as a field and the slope lay fallow. Today, the flat part consists mainly of permanent grass stands. 
The vegetation of the slope part of terrace was characterised by phytosociological relevés and these were consequently evaluated.

\section{Background research}

The usage of the term agricultural terrace in the text stems from Zapletal's characteristics (Zapletal, 1969). An agricultural terrace consists of a part that is flat and the slope of the terrace (Fig. 1). The results presented in this study describe the current situation on the slopes of the terraces and this is the meaning in which the term terrace is being used. Agricultural terraces are typical for a large part of Slovakian territory because they allowed fields to be founded even on slopes with declination of up to $35^{\circ}$. Lobotka (1955) lists the occurrence of terraces in Slovakia mainly in the areas of Kysuce Highlands, Javorníky, Vtáčník, Pohronský Inovec, Kremnica Hills, Slovak Ore Mountains, Upper Váh Region, Hron Region, Ipla Region, Orava, Spiš, Stráž Highlands, Krupina Highlands, etc.

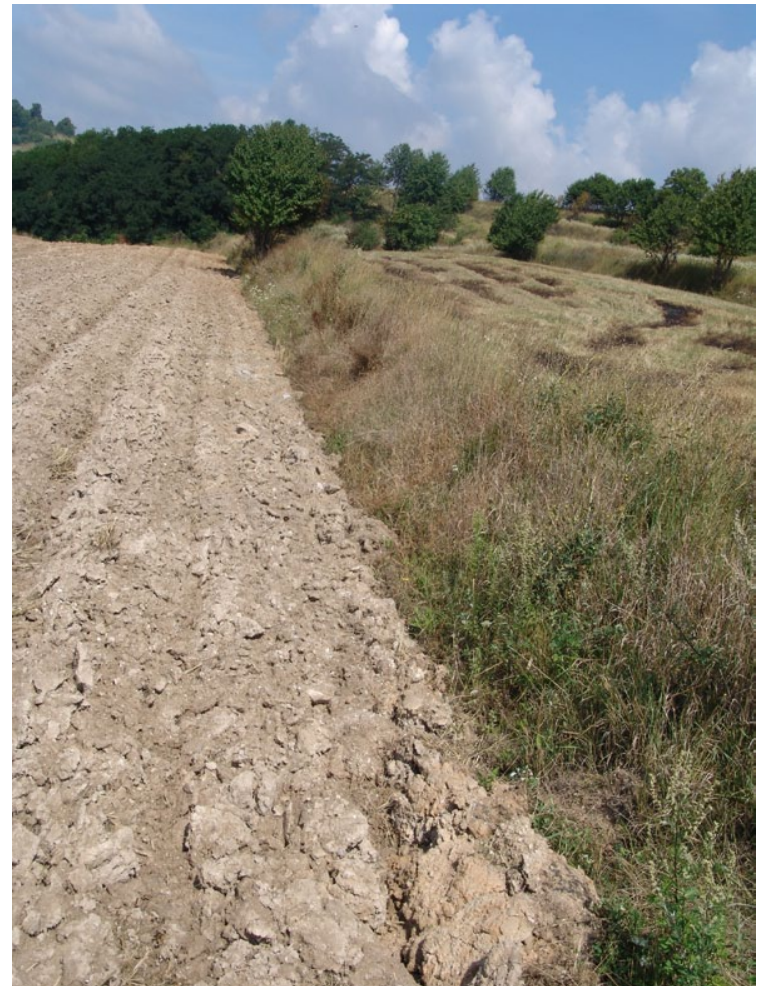

Fig. 1. Photographic documentation of an agricultural terrace.

Historical structures in agricultural landscape are what is at the forefront of scientific attention (Špulerová et al., 2011). One of the distinguished types consists of grass areas (meadows and pastures, fallow land) and fields very often in combination with terraces and stony hedgerows and walls. Their borderlines are copied by woody plants and forest remains. This type of landscape is widely found in the foothills, mainly in the Váh and Spiš regions, followed by, in the frequency of occurrence, the regions of Hron, Turčiany-Liptov-Orava, and Gemer-Nové Hrady. The necessity to detach historical landscape structures and create suitable conditions for their protection are discussed by Hrnčiarová (2004). On the example of Zamagurie, Dobrovodská (2004) documents the connection between historical development and landscape type. In the middle of the $16^{\text {th }}$ century near the village Osturná during pasture colonization, the settlers were allotted plots about 110-130 m wide. Inheritance divided the plots lengthwise, thus creating narrower and 
narrower fields. The balks consisted of soil or stony soil, often dozens of metres long with the occurrence of stone heaps as well. In the beginning of the $17^{\text {th }}$ century, when the village Malá Franková was founded, plots of the size of 17 ha were allotted but, when inherited, these were divided crosswise, not lengthwise. This influenced the segmentation of the present landscape, leading to estates that are square in shape and divided by massive stony walls.

The long history of the emergence of terraces is documented by the data from the surroundings of Liptovská Teplička where new fields (including terraced belt fields) were being founded ever since the year 1790 up until and including the $19^{\text {th }}$ century, accompanied by the emergence of various types of balks (Sperling, Žigrai, $1970 \mathrm{sec}$. Dobrovodská, Štefunková, 1996). In extreme cases, the belt field was only $4 \mathrm{~m}$ wide while the width of the terrace slope (the stony wall of the slope) was up to $20 \mathrm{~m}$. Ružičková et al. (1999) place the emergence of hedgerows and terraces in the Liptovská Teplička area as early as 1634.

Huba (2004) named two principal causes of endangerment of agricultural terraces in Slovakia. First, they cease to exist due to the need to adapt the landscape to match the needs of current technology. Second, it is due to the dilapidation and deterioration caused by the decline in traditional ways of land cultivation. He defines dilapidation and deterioration as onset of forest communities in accordance with the continuing succession. He considers it a moral obligation of the contemporary generation to identify the most characteristic historical landscape structures and protect them for future generations as, in current landscape, these structures are the most endangered.

In Bohemia, soil terraces and balks were being removed mainly during the period of the Communist land reform (collective farming) and the subsequent reforms from 1950s to 1970s. The slopes with the lowest declination displayed the greatest amount of balk removal as these were the areas most suitable for cultivation, as shown by the Czech Central Mountains study. Conversely, in areas with low pressure on landscape utilisation, woody plants proliferated on the hedgerows that remained (Machová, Elznicová, 2011). In the less intensively cultivated landscape of the Czech-Austrian border regions, forest areas became more prevalent over cultivated land, as well as scattered trees and shrubbery (Kubeš, Mičková, 2003). In Slovakia today the removal of terraces is being noted for the purposes of the improvement of the conditions of usage of agricultural machinery.

\section{Method}

Field investigations were carried out during the years 2009-2012, always in August. The localities were identified and discovered with regards to available literature (Lobotka, 1955) and also with the help of aerial photographs. The evaluation includes terraces from the territories of 13 districts lying in 12 mountain ranges that belong to the geomorphological areas of Slovak-Moravian Carpathians, Western Beskids, Central Beskids, Slovak Central Mountains, Fatra-Tatra Area, and Podhale-Magura Area. The mountain ranges were located using their map coordinates and the geomorphological area was determined according to Mazúr et Lukniš (1986). The localities were marked on maps in the software ArcGIS 10.1. The localities are situated close to the protected landscape areas Kysuca (Fig. 2), Ponitrie, Štiavnice Hills, Horná Orava, Polana (Fig. 3) and the national park Velká Fatra. Only some of the localities lie within the protected landscape territories, as listed with individual localities. 


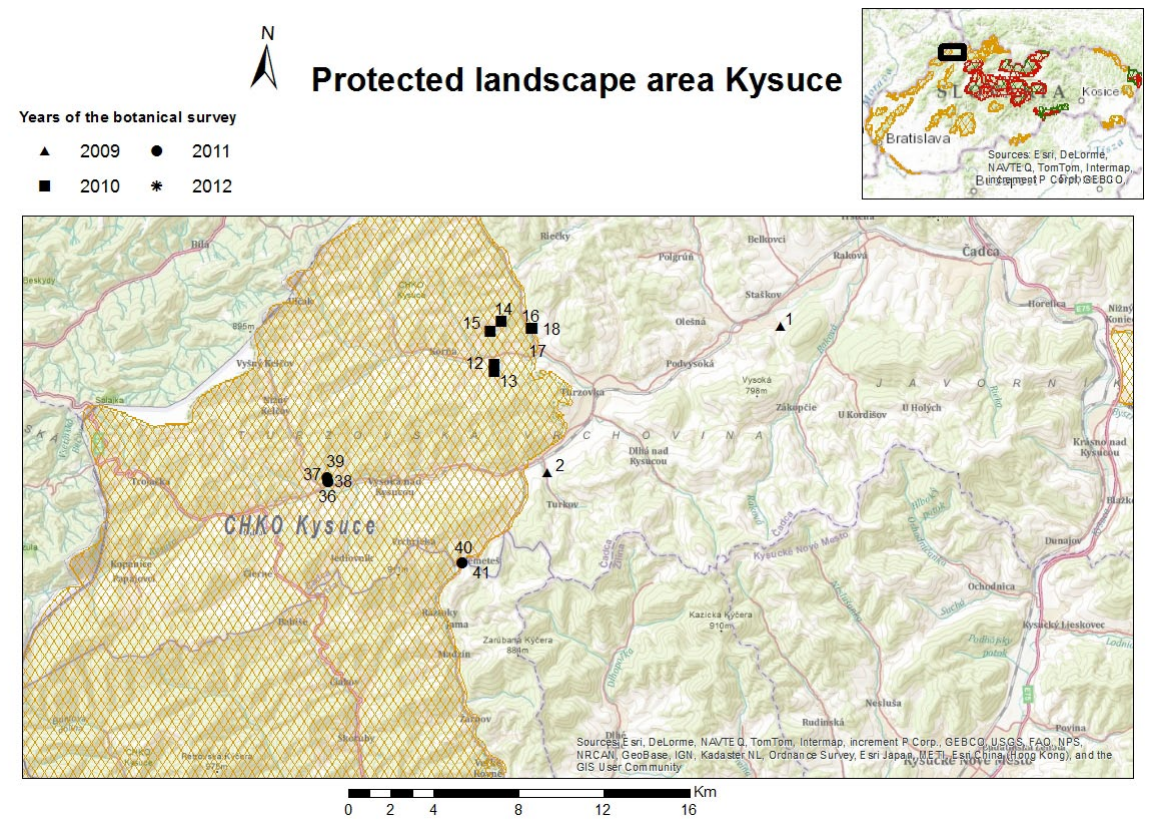

Fig. 2. Part of Slovakian territory with the borders of the protected landscape area Kysuce and the localities of the terraces.

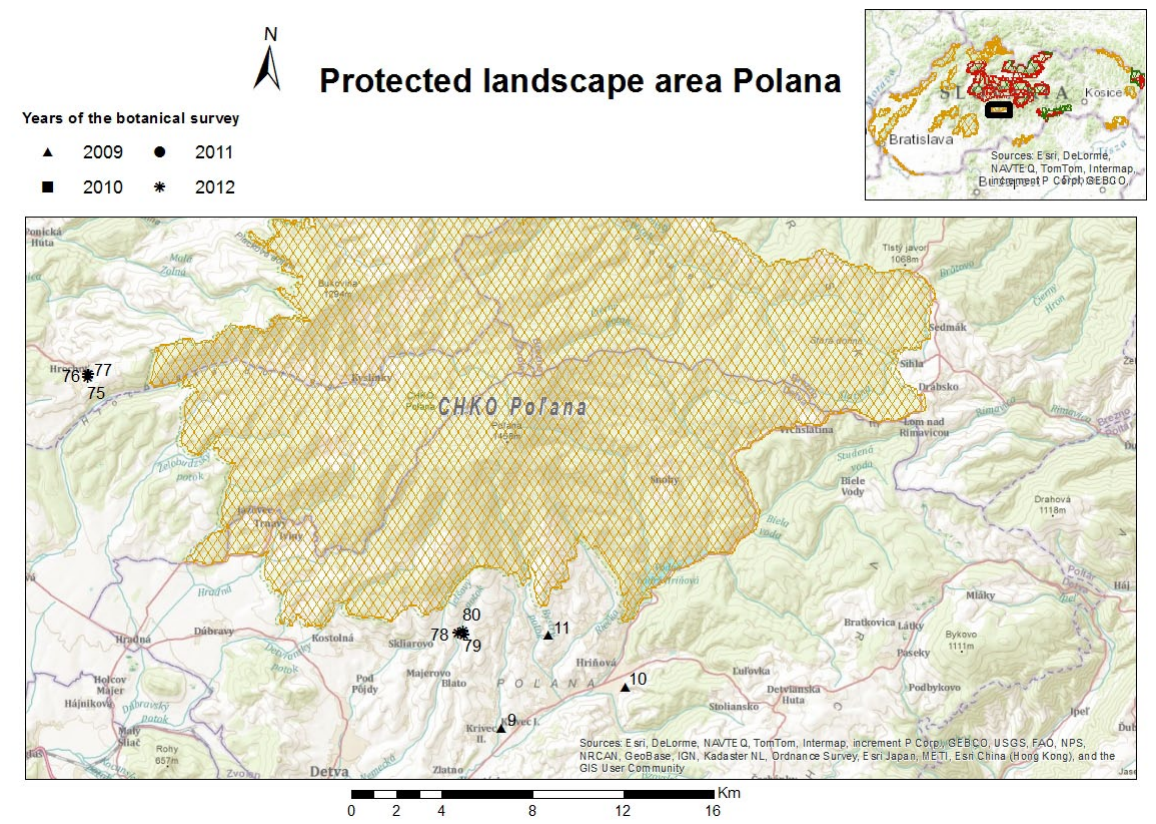

Fig. 3. Part of Slovakian territory with the borders of the protected landscape area Polana and the localities of the terraces. 
List of the relevés and their localities:

1 Staškov, distr. Čadca; Javorníky (Slovak-Moravian Carpathians),

2 Turzovka, distr. Čadca; Turzov Highland (Western Beskids),

3 Štiavnik, distr. Bytča; Javorníky (Slovak-Moravian Carpathians),

4,5 Lehota pod Vtáčnikom - Podhradie, distr. Prievidza; Vtáčnik (Slovak Central Mountains),

6,7 Nová Baňa, distr. Žarnovica; Pohronský Inovec (Slovak Central Mountains),

8 Turová, distr. Zvolen; foothills of the Kremnica Hills (Slovak Central Mountains),

9 Hriňová - Velký Slanec, distr. Detva; Polana foothills (Slovak Central Mountains),

10 Hriňová - Uhlisko, distr. Detva; Poĺana foothills (Slovak Central Mountains)

11 Horná Hriňová, distr. Detva; Polana foothills (Slovak Central Mountains),

12,13,14,15 Korňa, distr. Čadca; Turzov Highlands (Western Beskids), lies in protected landscape area Kysuca,

16,17,18 Turzovka, distr. Čadca; Turzov Highlands (Western Beskids), lies near the border of the protected landscape area Kysuca,

19,20 Skalité, distr. Čadca; Kysuce Beskids (Western Beskids),

21,22,23 Oščadnica, distr. Čadca; Kysuce Beskids (Western Beskids), nearing the border of the protected landscape area Kysuca,

24,25 Vyšný Kubín, distr. Dolný Kubín; Choč Hills (Fatra-Tatra area), national park Malá Fatra

26,27,28 Ružomberok - Hrboltová, distr. Ružomberok; foothills of Choč Hills (Fatra-Tatra area), neighbouring the NP Velká Fatra,

29,30 Ružomberok - Stará Černová, distr. Ružomberok; Velká Fatra foothills (Fatra-Tatra area), on the border of the protection zone of the NP Velká Fatra,

31,32 Nižná, distr. Tvrdošín; Orava Magura (Central Beskids),

33,34,35 Brezovica, distr. Tvrdošín; foothills of Skorušina Mountains (Podhale-Magura area)

36,37,38,39 Vysoká nad Kysucou - Nižný Kelčov, distr. Čadca; Turzov Highlands (Western Beskids), protected landscape area Kysuca,

40,41 between the villages Vysoká nad Kysucou a Velké Rovné, distr. Bytča; Javorníky (Slovak- Moravian Carpathians), protected landscape area Kysuca,

42,43,44 Radobica, distr. Prievidza; Vtáčnik (Slovak Central Mountains), nearing the border of the protected landscape area Ponitrie,

45,46,47 Jedlové Kostolany, distr. Žarnovica; Pohronský Inovec (Slovak Central Mountains),

48,49,50 Dolná Ves, distr. Žiar nad Hronom; Kremnica Hills (Slovak Central Mountains), 51,52,53 Sklabiňa, distr. Martin; foothills of Velká Fatra (Fatra-Tatra area),

54,55,56 Zborov nad Bystricou, distr. Čadca; Kysuce Beskids (Western Beskids), nearing the border of the protected landscape area Kysuca,

57,58, 59 Nová Bystrica, distr. Čadca; Kysuce Beskids (Western Beskids), protected landscape area Kysuca,

60,61,62 Breza, distr. Námestovo; Sub-Beskidian Highlands (Central Beskids), protected landscape area Horná Orava,

63,64, 65 Sihelné, distr. Námestovo; the foothills of Orava Beskids (Central Beskids), nearing the protected landscape area Horná Orava,

66,67,68 Zubrohlava, distr. Námestovo; Sub-Beskidian Highlands (Central Beskids), nearing the protected landscape area Horná Orava,

69,70,71,72,73,74 Zábiedovo, distr. Tvrdošín; foothills of Skorušina mountains (Podhale-Magura area), ( Fig. 4),

75, 76,77 Hrochot', distr. Bánská Bystrica; Polana foothills (Slovak Central Mountains),

78,79,80 Detva - Skliarovo, distr. Detva; Poĺana foothills (Slovak Central Mountains).

Stony hedgerows represent a minimum of the hedgerows and terraces found and therefore they have not been included in the evaluation. The study is based on Braun-Blanquet phytosociological relevés taken in the areas of soil or stony soil terraces. The area of a relevé is given by its length of $20 \mathrm{~m} \times$ the width of the terrace. The borders of the terraces were marked by the foot of the slope and its top edge. The results were presented by graphs using Microsoft Excel. The phytosociological relevés were analysed using indirect gradient analysis DCA (Detrended Correspondence Analysis) in the Canoco for Windows software (ter Braak, Šmilauer, 2002) in order to find the direction of the highest variability in the species composition of the hedgerow relevés. 70 relevés of comparable size were used for the analysis. Altitude was displayed only as a supplementary variable. Abbreviations of the plant species are listed 


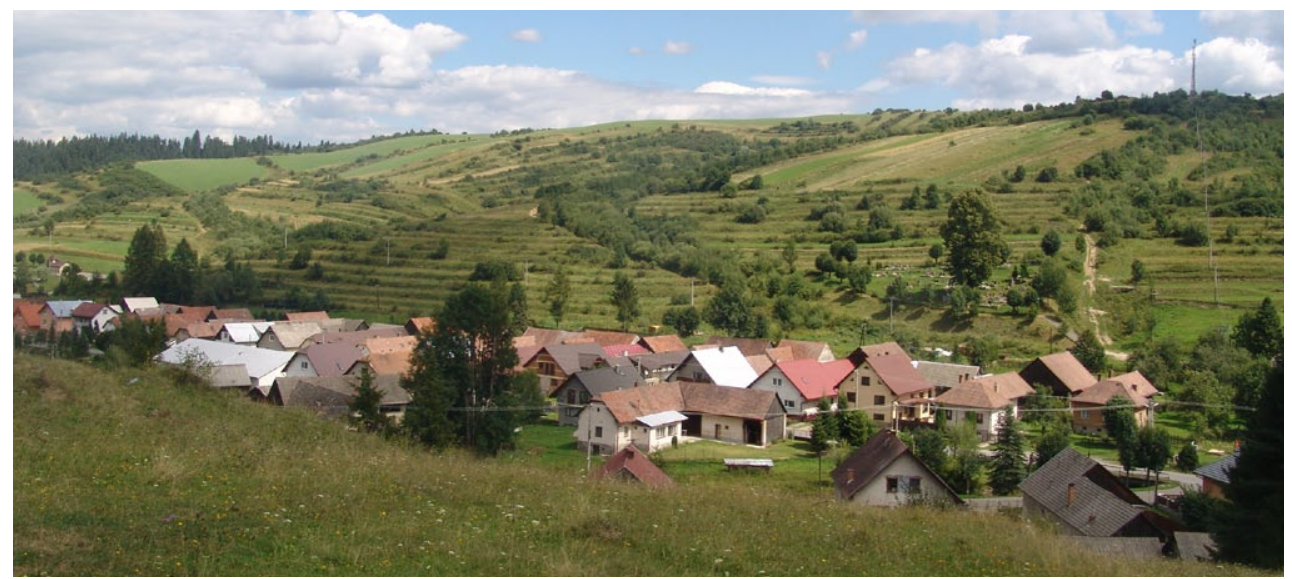

Fig. 4. Photographic documentation of the locale with agricultural terraces near the village Zábiedovo.

below the pictures. We used the nomenclature according to Kubát et al. (2002). Abbreviations of woody plant species have the numbers 1, 2, 3 listed in them, these refer to the layer in which the species was found (E1, E2, E3). Endangered species have been listed according to http://botany.cz/cs/ohrozene-rastliny-slovenska/. Symbols used in the Červený zoznam ohrozených druhov cievnatých rastlín Slovenska (The Red List of Threatened Species of Vascular Plants in Slovakia): CR - critically endangered species, VU - vulnerable species, NT - near threatened species.

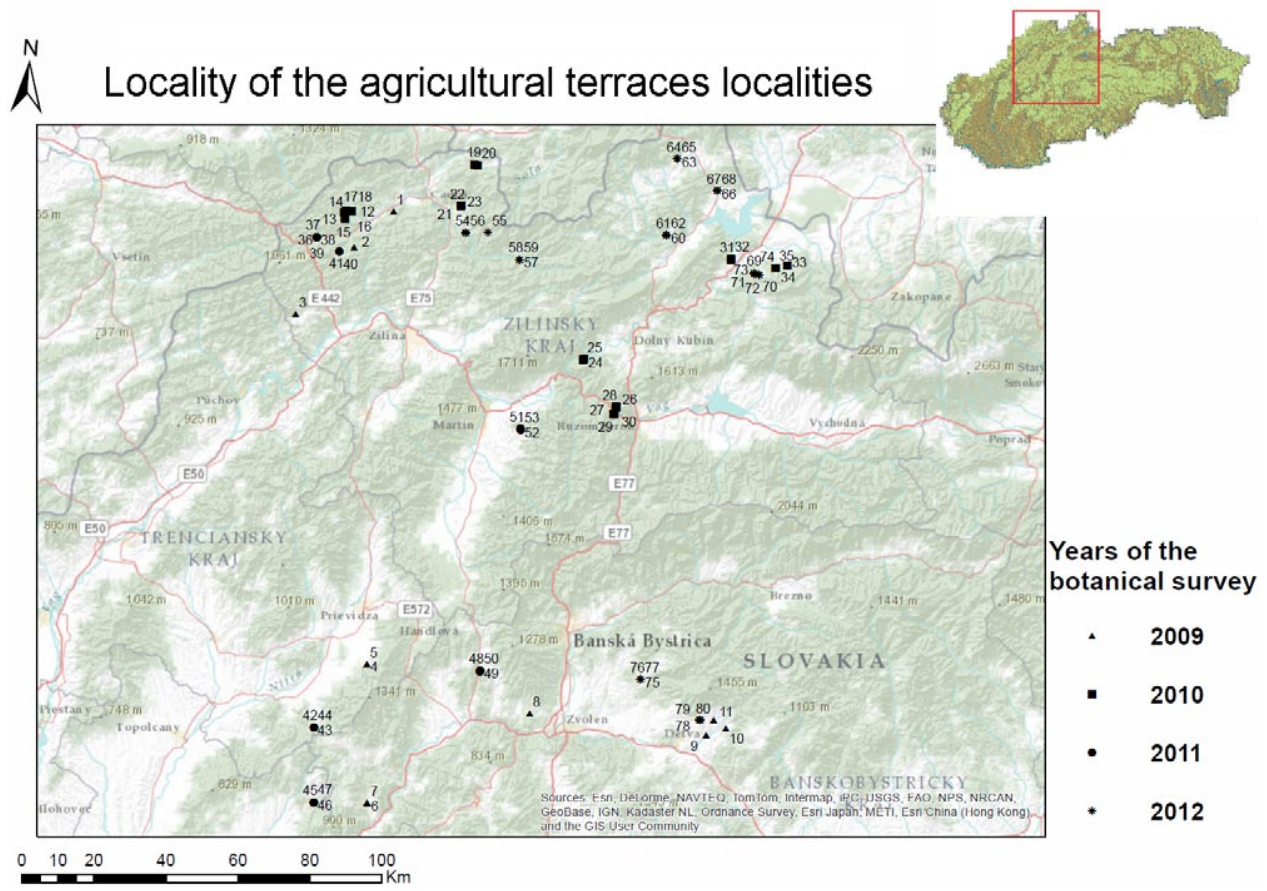

Fig. 5. Map of NW Slovakia with the locality of the agricultural terraces localities. 


\section{Results}

We studied 32 localities with the occurrence of agricultural terraces in NW Slovakia. The position of these localities is apparent from the map (Fig. 5). Markings on the map help to distinguish the year the botanical research was conducted in. Localities in the text are listed under the same number.

We compared variability of plant composition of phytocenological relevés in the north-east part of Slovakia using DCA analysis (Fig. 6). The set of 70 relevés of comparable size was chosen for the analysis. The altitude of relevés was used as a supplementary variable.

The differences between relevés were best explained by geological bedrock of studied area. The altitude of that area had also some effect.

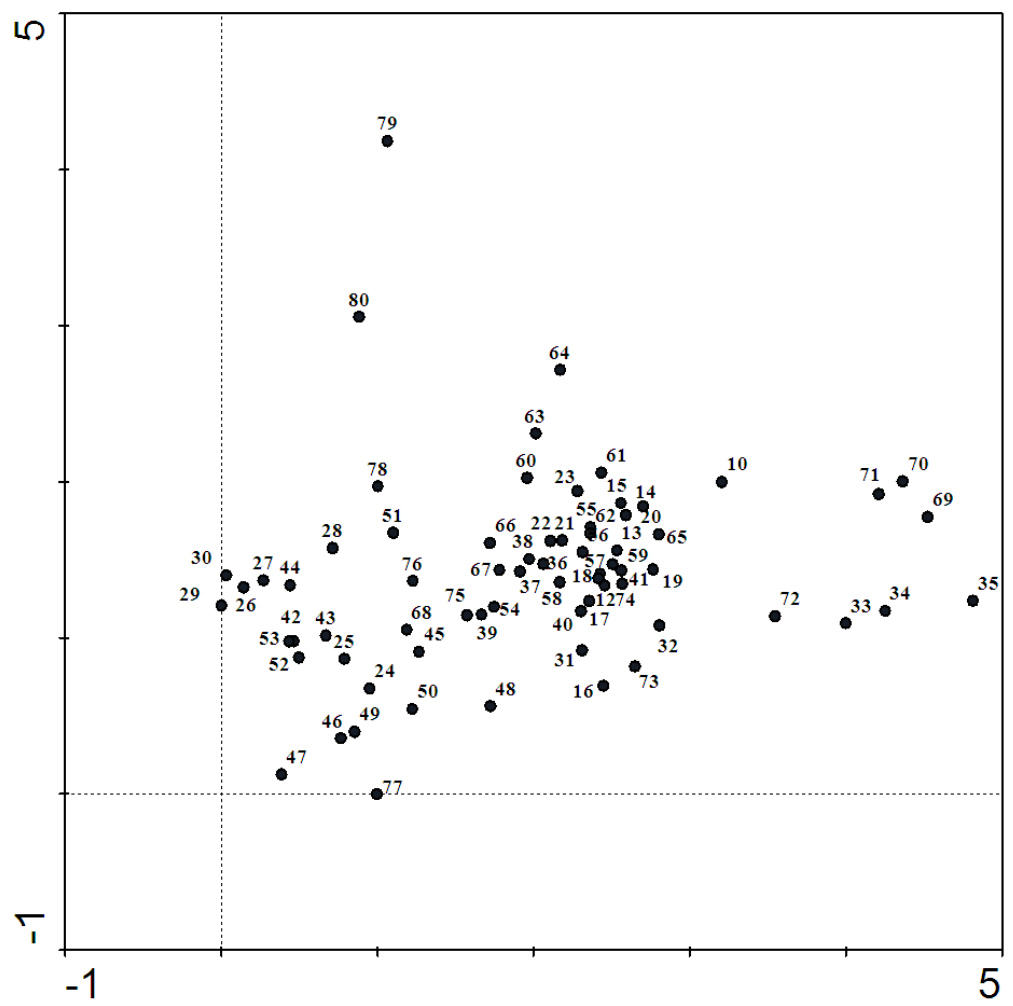

Fig. 6. DCA ordination plot with the localities.

Commentary: Based on the results of the DCA analysis, it was found that the right side of the plot contains those localities $(33,34,35,69,70,71,72)$ that, are in the area of Cretaceous period sandstone bedrock (see Geological maps, Fig. 7). The left side of the plot contains the localities $(24,25,26,27,28,29,30,42,43,44,52,53)$, which are laying in the area of bedrock from the Mesozoic era belonging to limestones, dolomites, and hornbledes (Fig. 8). Upper part of the plot contains localities $(78,79,80)$ from the area consisting of neogenic vulcanites with the prevalence of andesites. Discovered gradient is best described by geological area, where hedgerows are found.

The influence of altitude cannot be readily ruled out either. The right side of the plot contains localities laying in higher altitude (over 700 or $800 \mathrm{~m}$ ). The left side of the plot contains localities lying in lower altitude (300-500 m). 


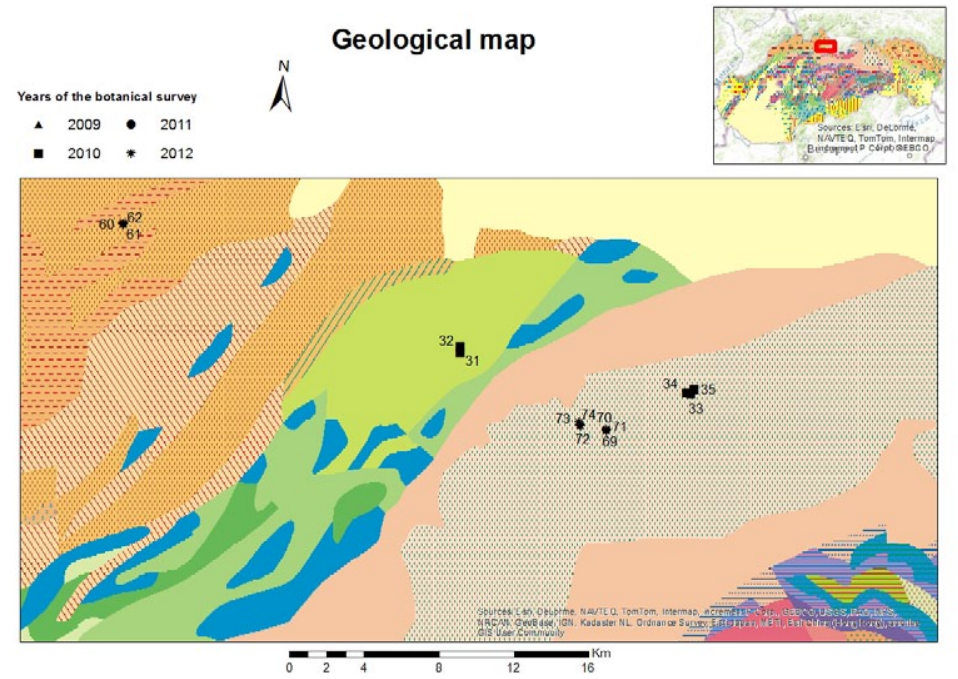

Fig. 7. Geological map with the display of the locality of the agricultural terraces (including legend).

Geological unit: Upper Cretaceous period and Palaeogene of Inner Western Carpathians, Age: Priabonian - Oligocene, Lithology: Sandstone.

Geological unit: Mesozoic and Palaeogene of the Pieniny klippen belt, Age: Maastrichtian - Eocene, Lithology: Sandstones, Claystones, Conglomerates.

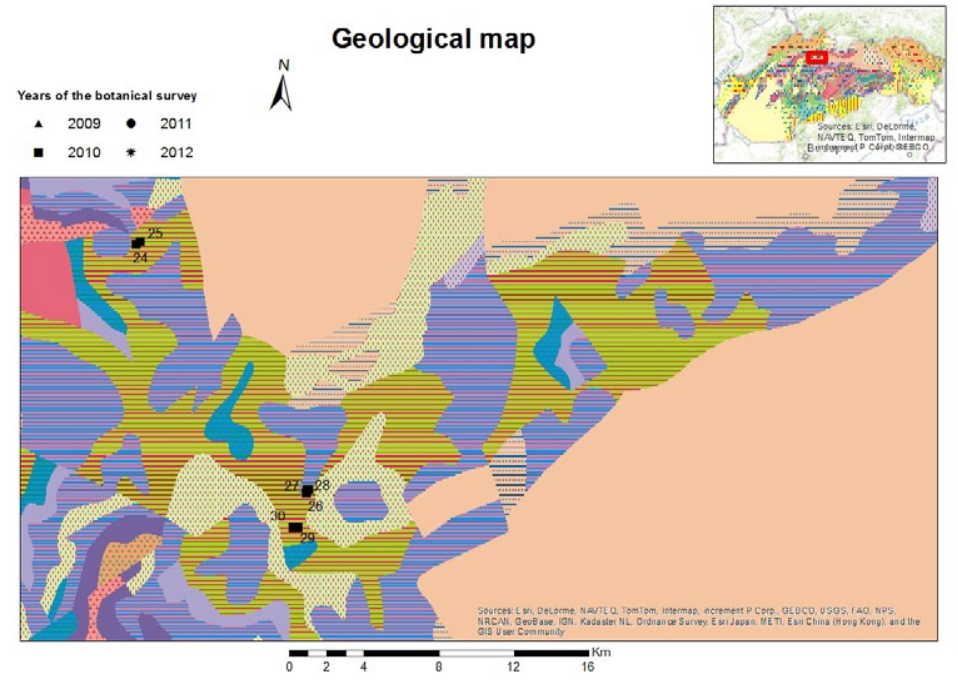

Fig. 8. Geological map with the display of the locality of the agricultural terraces (including legend).

Geological unit: Mesozoic of Inner Western Carpathians,

Age: Tithonian - Aptian, Lithology: Organodetritic limestones, marlstones and illitic shales with visible layers and content of clays and silica.

Geological unit: Mesozoic of Inner Western Carpathians, Age: Middle - Upper Triassic Lithology: Gutenstein limestone, Ramsau, main, and Wetterstein dolomites, Reifling limestones. 
The overall amount of vascular plant species found in the phytosociological relevés on the terraces is about 360 . This is relatively high number for relevés of a cultural landscape. Such a large number of species found informs us not only of the species diversity of the agricultural terraces but also reflects the fact that the research included 32 localities from a vast territory. The sources of species diversity are surrounding vegetation, the influence of natural conditions in the area with hedgerows and management of these localities. Only 66 species appeared more frequently than in $10 \%$ of the relevés (Fig. 9).

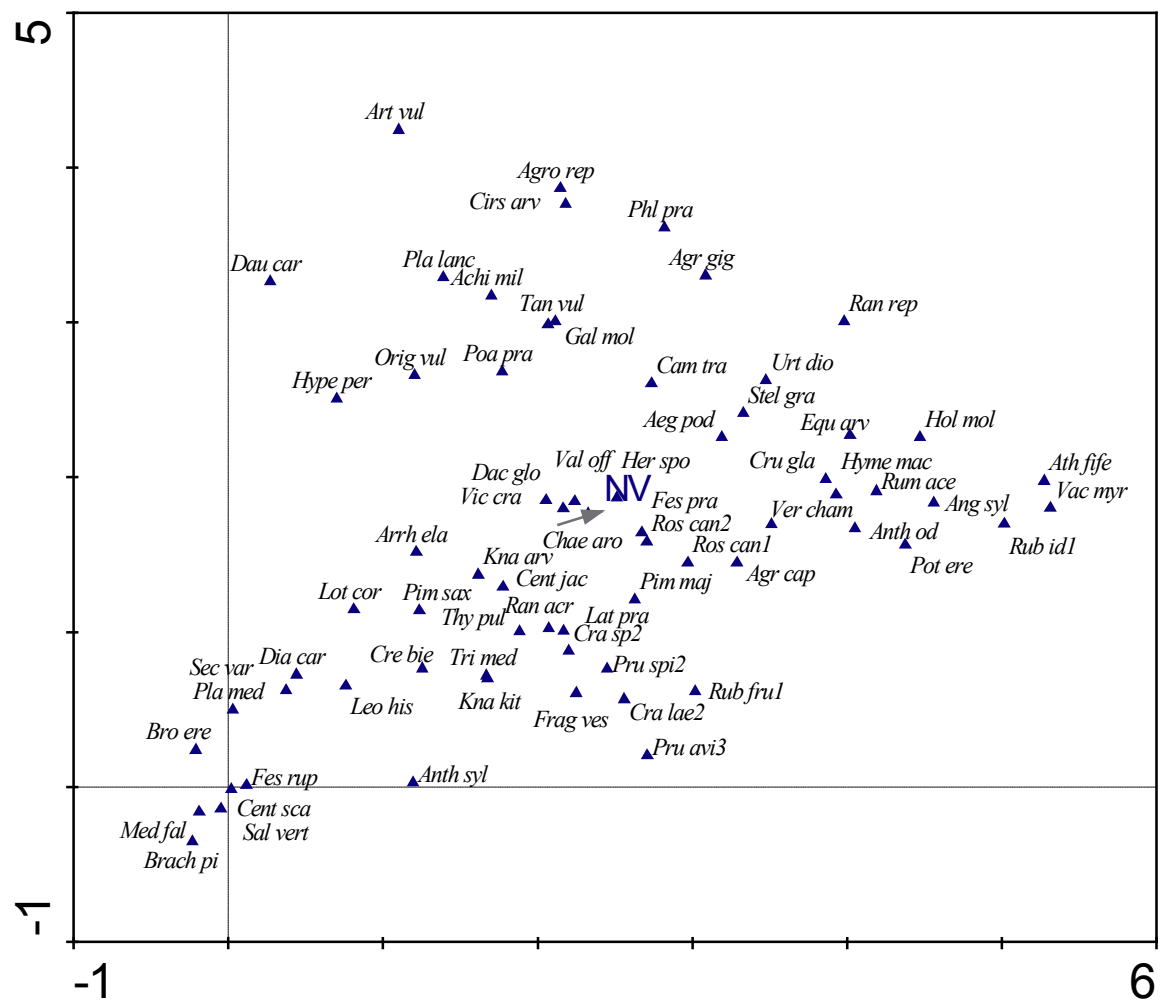

Fig. 9. DCA ordination plot. Only species with the weigh range f $10-100 \%$ are displayed.

Commentary: The first ordination axis can be matched with the gradient of $\mathrm{pH}$ or nutrients. The right side of the plot contains species typical for oligotrophic biotopes such as Athyrium filix-femina, Vaccinium myrtillus, Rubus idaeus, Potentilla erecta, Angelica sylvestris, Rumex acetosa, Hypericum maculatum, Holcus mollis. The left side contains species of alkaline biotopes such as Brachypodium pinnatum, Medicago falcata, Salvia verticillata, Centaurea scabiosa, Festuca rupicola, Bromus erectus, Plantago media, Securigera varia, Dianthus carthusianorum. The polarity of the species in the plot can also signify the influence of management, which is reflected by the gradient parallel to the second ordination axis. The bottom contains mainly woody plants, that needs longer period without a disruption: Prunus avium, Crataegus laevigata, Rubus fruticosus agg., Prunus spinosa, Crataegus sp., Rosa canina. The top contains mainly the species typical for agricultural land lying fallow Tanacetum vulgare, Galium mollugo, Achillea millefolium, Agrostis gigantea, Plantago lanceolata, Daucus carota, Phleum pratense, Cirsium arvense, Agropyron repens, Artemisia vulgaris. 
Abbreviations of the species' names: Achi mil - Achillea millefolium; Aeg pod - Aegopodium podagraria; Agro rep - Agropyron repens; Agr cap - Agrostis capillaris; Agr gig - Agrostis gigantea; Ang syl - Angelica sylvestris; Anth od - Anthoxanthum odoratum; Anth sylv - Anthriscus sylvestris; Arrh ela - Arrhenatherum elatius; Ath fife - Astragalus glycyphyllos; Brach pi - Brachypodium pinnatum; Bro ere - Bromus erectus; Cam tra - Campanula trachelium; Cent jac Centaurea jacea; Cent sca - Centaurea scabiosa; Chae aro - Chaerophyllum aromaticum; Cirs arv - Cirsium arvense; Cra lae - Crataegus laevigata; Cra sp - Crataegus sp.; Cre bie - Crepis biennis; Cru gla - Cruciata glabra; Dac glo - Dactylis glomerata; Dau car - Daucus carota; Dia car - Dianthus carthusianorum; Equ avr - Equisetum arvense; Fes pra - Festuca pratensis; Fes rup - Festuca rupicola; Frag ves - Fragaria vesca; Gal mol - Galium mollugo agg; Her spo - Heracleum spondylium; Hol mol - Holcus mollis; Hyme mac - Hypericum maculatum; Hype per - Hypericum perforatum; Kna arv Knautia arvensis; Kna kit - Knautia kitaibelii; Lat pra - Lathyrus pratensis; Leo his - Leontodon hispidus; Lot cor - Lotus corniculatus; Med fal - Medicago falcata; Orig vul - Origanum vulgare; Phl pra - Phleum pratense; Pim maj - Pimpinella major; Pim sax - Pimpinella saxifraga; Pla lanc - Plantago lanceolata; Pla med - Plantago media; Poa pra - Poa pratensis; Pot ere - Potentilla erecta; Pru avi - Prunus avium; Pru spi - Prunus spinosa; Ran acr - Ranunculus acris; Ran rep - Ranunculus repens; Ros can - Rosa canina; Rub fru - Rubus fruticosus agg.; Rub id - Rubus idaeus; Rum ace - Rumex acetosa; Sal vert - Salvia verticillata; Sec var -Securigera varia; Tan vul - Tanacetum vulgare; Thy pul - Thymus pulegioides; Vac myrt - Vaccinium myrtillus; Val off - Valeriana officinalis; Ver cham - Veronica chamaedrys; Vic cra - Vicia cracca.

Of all 360 species, only 9 are among endangered species. This is perhaps because biotopes on the terraces are common and widely spread biotopes. Certain endangered species were found Agrostemma githago (CR), Allium carinatum (VU ), Centaurea cyanus (NT), Dactylorhiza fuchsii (VU), Epipactis palustris (VU), Gentiana cruciata (NT ), Gladiolus imbricatus (VU), Gymnadenia conopsea (VU), Senecio doria (CR).

The phytosociological relevés also provide quantitative characteristics of the vegetation. Box plots were created from the values found on terraces. These plots show the coverage esti-

\section{Growth Coverage According to the Phytosociological Relevés}

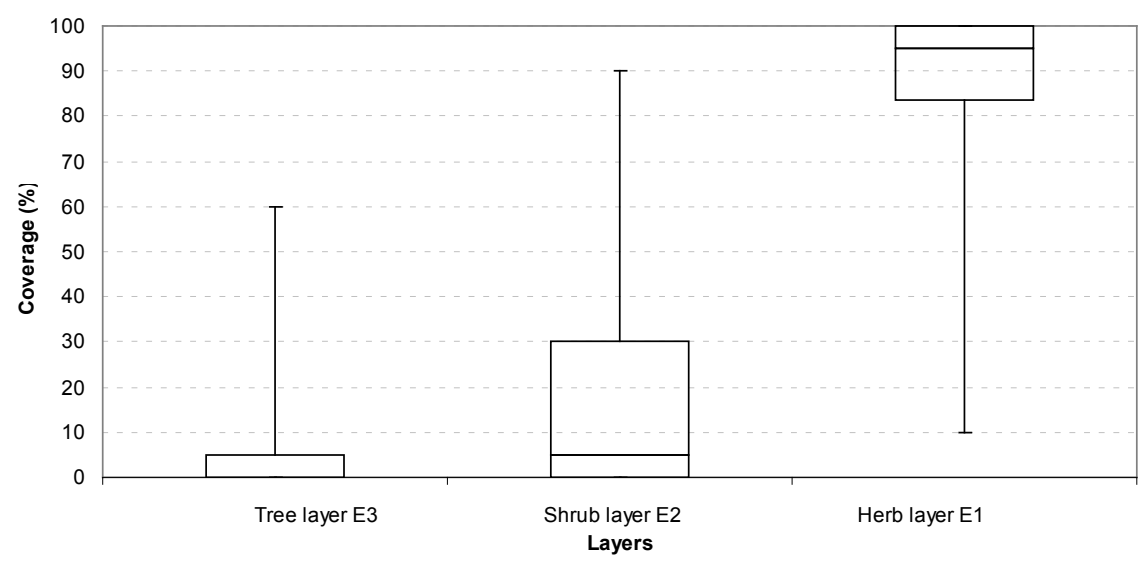

Fig. 10. Depiction of percentual coverage of plant coverage of individual layers of the terraces.

Commentary: The graph makes it apparent that the tree layer, if present at all, usually reaches the coverage of $5 \%$ (third quartile). Exceptionally, the maximum coverage was as high as $60 \%$. The median value for the shrub layer is $5 \%$, the usual figure for coverage is $30 \%$ (third quartile) and the maximum is $90 \%$. The median value in the herb layer is $95 \%$, first quartile is $84 \%$ and the minimum is $10 \%$. Third quartile is $100 \%$. 
mate for the tree layer E3, shrub layer E2, and herb layer E1; the median of the tree layer has zero value, $5 \%$ for the shrub layer and $95 \%$ for the herb layer (Fig. 10).

An important characteristic, especially from the landscape and practical viewpoint, was also the ratio of the width of the terrace slope and the width of the flat part of the terrace. Based on the measurements and calculation, Fig. 11 was created. The width of the terrace slope is actual area of the agricultural terrace which was recorded using phytosociological relevés. The width of the flat part of the terrace was or is used as agricultural land for cultivation (a field, a meadow or lying fallow).

\section{Comparison of the Width of the Sloped and Flat Part of the Terrace}

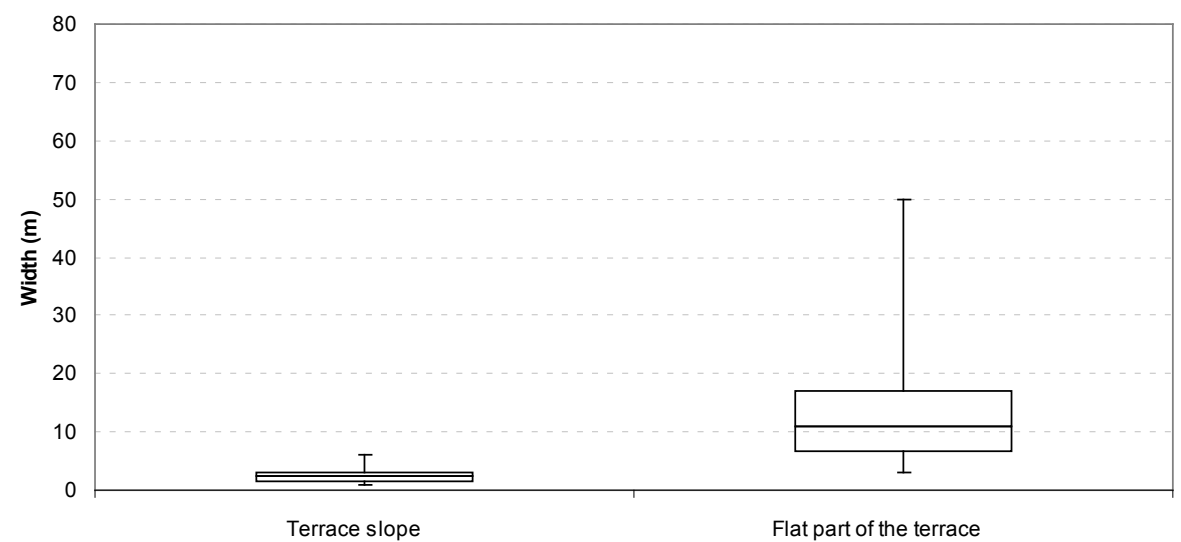

Fig. 11. The box plot depicts the width of the agricultural terrace (the slope) compared to the width of the flat part of the terrace next to the slope (Fig. 1).

Commentary: The graph shows that the differences between the values of the width of the terrace slopes are negligible and they are generally close to their average value of $2.3 \mathrm{~m}$. The first quartile is $1.6 \mathrm{~m}$ and the third quartile is $3.05 \mathrm{~m}$. Minimum width was $0,85 \mathrm{~m}$, maximum $6.1 \mathrm{~m}$. The width of the flat part of the terrace, i.e. the cultivated area itself, has its mean value of $11 \mathrm{~m}$ and the first and third quartile fall within the range 6.6-17 m. Maximum width values of the cultivated areas are often caused by the removal of one of the terrace slopes from the system and the subsequent leveling and merging of the areas.

\section{Discussion}

An analysis of the biology of the species found on agricultural terraces and slopes in the Czech Republic was performed. Prevalent types of diaspora propagations within colonisation of agricultural hedgerows and terraces were investigated. A relatively abundant presence of woody plants on hedgerows and terraces made it possible (by the analysis of growth rings) to estimate their temporal onset (Machová, Klazar, 2005). Dominant woody plants were also used for the vegetation classification; Riezner (2007) distinguishes hedgerows with lime-tree growth and 
sycamore growth. He also identified the complete species composition for the hedgerows of the Zlaté Hory region in Jeseníky. Similarly detailed study has also been made for hedgerows in Czech Central Mountains (Machová, 2011) and in Ore Mountains (Machová, Kubát, 2012).

A considerable portion of hedgerows in the Czech Republic was, in the long term, excluded from agricutular cultivation and the currently dominant element of hedgerows and agricultural terraces is formed by woody plants. Forests can be viewed as a potential source of forest species for the hedgerows (Machová et al., 2010). The character of the vegetation of the hedgerows shows similarities to the shrub strip around forests. These differ in terms of their species composition. For example, more prevalent species of woody plants in the foot of the Oblík Hill in the part of the Czech Central Mountains in the vicinity of the town Louny are Fraxinus excelsior, Crataegus sp., Rosa canina, Ribes uva-crispa, Rhamnus cathartica, Prunus spinosa, Ligustrum vulgare, Cornus sanguinea (Machová et al., 2009). In the Verneřice part of Czech Central Mountains, higher frequency of occurrence is reached by Fraxinus excelsior, Sambucus nigra, Corylus avellana, Crataegus sp. (Machová, 2011). Lower forest coverage on exposed hedgerows in the top parts of Ore Mountains is apparent from the fact that a higher frequency of occurrence (more than 50\% of the area) is reached only by Sorbus aucuparia (Machová, Kubát, 2012). Dominant woody plant species from Javorníky in northern Moravia according to Fischerová (2011) are Acer pseudoplatanus, Sorbus aucuparia, Fagus sylvatica, Abies alba, Fraxinus excelsior, Prunus avium, Rosa canina, Sambucus nigra a Ribes uva-crispa. The differences in more abundant woody species between the regions indicate that the woody plants of hedgerows and terraces (and, similarly, herbs) reflect the natural conditions of the area rather than a specific property of the hedgerows.

Low occurrence of woody plants on terraces in NW Slovakia (0-5\%) had a negative effect on the occurrence of forest herb species even in spite of the fact that a considerable number of the hedgerows is located near a forest. A high degree of inclination of the soil terraces leads to landslides, and as a consequence to the damage of the stands, the initial phase of succession begins. The low occurrence of woody plants on terraces can be the effect or one of the causes of the repeated erosion.

In NW Slovakia, terraces that are narrow prevail and the species composition does not much differ from the surrounding, mainly grass stands. There is also a difference between hedgerows and surrounding land in the quantitative composition of the species. More herbs on terraces belong to the meadow and pasture species and nitrophilous species.

Critically endangered species were not found, only threatened species appeared.

The differences between hedgerows in the Czech Republic and in Slovakia exist also in terms of landscape ecology. The terraces in NW Slovakia are narrower, their usual width is about $2.3 \mathrm{~m}$, ranging from $0.85-6.1 \mathrm{~m}$. In Ore Mountains, the width of the hedgerows varies between 3 and $8(-12) \mathrm{m}$ (Machová, Kubát, 2012). In Slovakia, terraces run prevailingly parallel to map contour lines whereas in the Czech Republic stony hedgerows prevail. Soil terraces parallel to the contour are less frequent (Machová, Elznicová, 2011). The influence of the presence of hedgerows and terraces on the character of the landscape is significant. This is shown by Dobrovodská (2004) comparing two neighbouring villages (Osturná and Malá Franková) with different divisions of land. As a result of historical development the surrounding land plots of Osturná are longer in shape, unlike around Malá Franková where they are square. This is 
apparent in the landscape through the presence of solitary woody plants on the soil terraces or stony hedgerows.

In the Czech Republic, historical changes in hedgerows were also studied especially in the $20^{\text {th }}$ century which saw significant political and economical changes with the subsequent dismantling of balks or, on the contrary, with the expansion of the area of growth on hedgerows and terraces (Machová, 2007; Elznicová, Machová, 2009, 2010).

\section{Conclusion}

Agricultural terraces in NW Slovakia are unevenly distributed. In some areas they were kept; in others, they disappeared and their removal is still in progress. All the terraces found are located in cultural landscape outside of forest. Only sporadically is the area with the terraces a part of a protected landscape area (Fig. 2). The areas are more often found in close neighbourhood or near a protected landscape area (Fig. 3), as these are usually defined by forests outside agricultural landscape.

The flora and vegetation of agricultural terraces was studied in 32 localities. Phytosociological relevés revealed 360 species of vascular plants. These species mostly belong to ruderal and meadow species, field weeds and woody plants; endangered species were few and far between. Agricultural terraces represent places of refuge for species that can spontaneously succeed in fallow fields. The structure of the vegetation on agricultural terraces is characterised by the high coverage of the herb layer and low or non-existent coverage of the shrub and tree layer. Forest herb species do not appear. Agricultural terraces are not biotopes with conditions different from those of the surrounding land. That is why it is understandable that the flora of the terraces and of the surrounding land is similar. This similarity is greater in Slovakia than on terraces or hedgerows in the Czech Republic.

Differences between the localities are best explained through the geological bedrock. The gradient of more frequent species of vascular plants can be explained by the availability of nutrients, $\mathrm{pH}$, altitude, and management. A decisive influence of natural conditions in the territory of the terraces was therefore confirmed.

Agricultural terraces run along the contour line, their inclination is great and they are narrow. The flat part of the terrace that was or is used for farming is narrow, too. The character of the terraces in Slovakia is unique, it is different from that of the terraces and hedgerows in the Czech Republic.

\section{Acknowledgements}

The article was written with the support of IGA: Flora of the Agricultural Terraces in NW Slovakia and its Causes. We would like to thank Bc Martina Mynárová for the processing of the maps and the data and Bc. Veronika Svítková for the processing of the maps in the scope of the solution of this project. We would also like to thank Mgr. Ladislava Filipová $\mathrm{PhD}$ for the processing of the graphs in the Canoco software.

\section{References}

Dobrovodská, M. (2004). Historické polnohospodárské formy využitia krajiny - relikt alebo fenomén budúcnosti? Životné Prostredie, 38(2), 94-97.

Dobrovodská, M. \& Štefunková D. (1996). Historické polnohospodárske formy antropogénneho reliéfu v oráčinovo- 
lúčno-pasienkárskej a vinohradnickej krajine. Acta Environmentalica Universitatis Comenianae (Bratislava), 7 , 85-91.

Elznicová, J. \& Machová I. (2009). Identifikace změn rozšíření agrárních valů. In D. Hübelová (Ed.), Geografické aspekty stredoevropského prostoru (pp. 84-96). Brno: Masarykova univerzita.

Elznicová, J. \& Machová I. (2010). Identifikace změn rozšiření agrárních valů na úpatí vrchu Oblíku. Studia Oecologica, $4(4), 5-14$.

Fischerová, N. (2011). Agrární haldy východní části Javorniku․ Bakalářská práce, PřF UP, Olomouc.

Gábová, K. (1997). Vegetace zemědělských hald u Malé Morávky ve vztahu k ekologickým faktorům prostředí. Diplomová práce, PřF UP, Olomouc.

Hrnčiarová, T. (2004). Prírodné a kulturné aspekty krajiny a jej potenciál. Životné Prostredie, 38(2), 61-65.

Huba, M. (2004). Historické štruktúry krajiny v kontexte súčasnej reality. Životné Prostredie, 38(2), 86-89.

Kubát, K., Hrouda, L., Chrtek, J. jun, Kaplan, Z., Kirschner, J. \& Štěpánek J. (Eds.) (2002). Klič ke květeně České republiky. Praha: Academia.

Kubeš, J. \& Mičková K. (2003). Development of horizontal landscape structure in the Pohořsko region (the CzechAustrian frontier) between 1938-2000. Ekológia (Bratislava), 22(3), 269-283.

Lobotka, V. (1955). Terasové polia na Slovensku. Poĺnohospodárstvo, 2(6), 539-549.

Machová, I. \& Klazar R. (2005). Věková struktura dřevin na agrárních valech. Severočeskou Př́rodou, 36-37, 111-121.

Machová, I. (2007). Sledování vývoje krajiny Českého středohoří na příkladu agrárních valů. Studia Oecologica, 1, 57-62.

Machová, I. \& Novák P. (2008). Přirozené zdroje a způsoby šíření rostlin na agrární valy a terasy. Studia Oecologica, 3, 86-92.

Machová, I., Filipová, L. \& Fiedlerová K. (2008). Dřeviny agrárních valů Českého stř̌edohoří a jejich vliv na bylinné patro. Severočeskou Př́rodou, 39, 1-6.

Machová, I., Kubát, K., Česká, J. \& Synek V. (2009). Vyhodnocení výskytu cévnatých rostlin z agrárních valů a teras na úpatí vrchu Oblíku v Českém středohoří. Př́roda, 28, 185-202.

Machová, I., Elznicová, J. \& Synek V. (2010). Význam agrárních valů a teras jako migračního prostředí lesních druhů. Severočeskou Př́rodou, 41, 75-82.

Machová, I. (2011). Floristicko-fytocenologická studie agrárních valů v CHKO České středohoří. Disertační práce, ČZU, Praha.

Machová, I. \& Elznicová J. (2011). Změny agrárních valů a teras ve Verneřickém Středohoří a jejich monitorování s využitím nástrojů GIS. In J. Kolejka a kol. (Eds.), Krajina Česka a Slovenska v současném výzkumu (pp. 180-196). Brno: Masarykova univerzita.

Machová, I. \& Kubát K. (2012). Flóra agrárních valů z vrcholových partií Krušných hor. Studia Oecologica, 2(12), 36-44.

Mazúr, E. \& Lukniš M. (1986). Geomorfologické členenie SSR s ČSSR. Čast’ Slovensko. Bratislava: Slovenská kartografia.

Riezner, J. (2007). Agrární formy reliéfu a jejich vegetace v kulturní krajině Jesenicka. Disertační práce, MU, Brno.

Ružičková, H., Dobrovodská, M. \& Valachovič M. (1999). Landscape-ecological evaluation of vegetation in relation to the forms of antropogenic relief in the cadastre of Liptovská Teplička village, the Nizké Tatry Mts. Ekológia (Bratislava), 18, 381-400.

Sklenička, P., Molnarová, K., Brabec, E., Kumble, P., Bittnerová, B., Pixová, K. \& Salek M. (2009). Remnants of medieval field patterns in the Czech Republic: Analysis of driving forces behind their disappearance with special attention to the role of hedgerows. Agric. Ecosyst. Environ., 129, 465-473. DOI: 10.1016/j.agee.2008.10.026.

Sperling, W. \& Žigrai F. (1970). Siedlungs- und agrargeographische studien in der Gemarkung der Gemeinde Liptovská Teplička. Geografický Časopis, 22, 97-130.

Špulerová, J., Dobrovodská, M., Lieskovský, J., Bača, A., Halabuk, A., Kohút, F., Mojses, M., Kenderessy, P., Piscová, V., Barančok, P., Gerhátová, K., Krajčí, J. \& Boltižiar M. (2011). Inventory and classification of historical structures of the agricultural landscape in Slovakia. Ekológia (Bratislava), 30(2), 157-179. DOI: 10.4149/ekol_2011_02_157.

ter Braak, C.J.F. \& Šmilauer P. (2002). Canoco for Windows. Version 4.5. Centre for Biometry Wageningen. Wageningen: CPRO - DLO.

Zapletal, L. (1969). Úvod do antropogenní geomorfologie. Olomouc: PřF UP.

http://botany.cz/cs/ohrozene-rastliny-slovenska/ - 21.12.2012 